\title{
Producción de leche de vacas Criollo, Guzerat y sus cruzas recíprocas $F 1$ y su relación con el peso al destete de las crías
}

\section{Milk yield and its relationship to weaning weight of calves from Criollo, Guzerat and F1 reciprocal cross cows}

\author{
Guillermo Martínez Velázqueza, Aurelio Borrayo Zepeda ${ }^{a}$, Moisés Montaño Bermúdezb, \\ José de Jesús Bustamante Guerreroa ${ }^{a}$ José Antonio Palacios Fránqueza ${ }^{\text {, Vicente Eliezer }}$ \\ Vega Murilloc, Ángel Ríos Utrera ${ }^{\mathrm{a}}$
}

\section{RESUMEN}

Se analizaron 208 registros obtenidos entre 2001 y 2003 de vacas Guzerat (G), Criollo (C), Guzerat x Criollo (GC) y Criollo x Guzerat (CG) para estimar efectos genéticos directos $\left(\mathrm{g}^{\mathrm{i}}\right)$, maternos $\left(\mathrm{g}^{\mathrm{m}}\right)$ y de heterosis $\left(\mathrm{h}^{\mathrm{i}}\right)$ sobre día de máxima producción (DMP), producción máxima en lactancia (PML), producción total de leche (PTL), producción diaria de leche (PDL), persistencia de la lactancia (PER) y para estimar relaciones entre PTL y peso al destete ajustado a 210 días de edad (PA210). La curva de lactancia se estimó mediante la ecuación $\mathrm{Y}(\mathrm{n})=\mathrm{n} / \boldsymbol{a} \mathrm{e}^{\mathrm{k}} \mathrm{n}$. Las variables se analizaron con el método de cuadrados mínimos y modelos mixtos. Los modelos incluyeron grupo genético, número, año y época de parto, sexo, la covariable peso al nacer e interacciones simples. Se estimaron correlaciones y regresiones entre PA210 y PTL. Las vacas GC fueron superiores a vacas C y G para PML, PTL y PDL $(P<0.10)$. La $h^{\mathrm{i}}$ influyó $(P<0.05)$ PML, PTL y PDL. Los gi favorecieron a G $(P<0.05)$ en PML, PTL y PDL. Las correlaciones fueron importantes $(P<0.05)$ para todos los grupos genéticos. Los coeficientes de regresión fueron $0.044 \pm 0.014(C), 0.037 \pm 0.014(G C)$, $0.032 \pm 0.009$ (G) y $0.027 \pm 0.015$ (CG). Crías de vacas C, GC, G y CG consumieron 22.5, 27.3, 30.9 y $37.3 \mathrm{~kg}$ de leche por cada kilogramo de peso al destete. Las diferencias estimadas en la eficiencia de utilización de la leche consumida por las crías sugieren que la producción de becerros con vacas C, GC, G y CG debe considerar estrategias diferentes de alimentación durante la lactancia.

PALABRAS ClAVE: Bovinos carne, Destete, Heterosis, Criollo.

\begin{abstract}
Data were collected between 2001 and 2003 from Guzerat (G), Criollo (C), Guzerat x Criollo (GC), and Criollo x Guzerat (CG) cows $\left(\mathrm{n}=\mathbf{2 0 8}\right.$ records) to estimate heterosis $\left(\mathrm{h}^{\mathrm{i}}\right)$ and direct $\left(\mathrm{g}^{\mathrm{i}}\right)$ and maternal $\left(\mathrm{g}^{\mathrm{m}}\right)$ genetic effects for day of peak milk yield (DMP), maximum milk yield (PML), total milk yield (PTL), daily milk yield (PDL), persistency of lactation (PER), and to estimate relationships between PTL and weaning weight adjusted to $210 \mathrm{~d}$ of age (PA210). Lactation curve was estimated by the equation Y(n)=n/ae $\mathrm{kn}$. Variables were analyzed with least squares procedures and mixed models. Final models included effects of genotype of the cow, number, year and season of calving, sex of calf, birth weight as a covariate and two factor interactions. Correlations and regressions were estimated between PA210 and PTL. GC cows had greater production for PML, PTL and PDL $(P<0.10)$ than $C$ and G cows. $h^{i}$ was important $(P<0.05)$ for PML, PTL and PDL. gi were favorable to G $(P<0.05)$ for PML, PTL and PDL. Correlations were important $(P<0.05)$ for all genetic groups. The regression coefficients were $0.044 \pm 0.014(C), 0.037 \pm 0.014(G C), 0.032 \pm 0.009(G)$ and $0.027 \pm 0.015$ (CG). Calves from C, GC, G and CG cows required 22.5, 27.3, 30.9 and $37.3 \mathrm{~kg}$ of milk per each kilogram of weight at weaning. The differences in the efficiency of utilization of milk consumed by calves suggest that different strategies of feeding during lactation should be considered for the production of feedlot calves with C, GC, G and CG cows.
\end{abstract}

KEY WORDS: Beef cattle, Milk production, Weaning weight, Criollo.

\footnotetext{
Recibido el 20 de mayo de 2011. Aceptado el 2 de agosto de 2011

a Sitio Experimental "El Verdineño", Instituto Nacional de Investigaciones Forestales, Agrícolas y Pecuarias (INIFAP), Edificio SAGARPA Av. Insurgentes \# 1050 Ote. Col. Menchaca 63150 Tepic, Nayarit, México. Tel (323) 23 50710. martinez.guillermo@inifap.gob.mx Correspondencia al primer autor.

b Centro Nacional de Investigación Disciplinaria en Fisiología y Mejoramiento Animal. INIFAP.

c Campo Experimental La Posta, Centro de Investigación Regional del Golfo Centro. INIFAP.
} 
En bovinos productores de carne las diferencias en producción de leche de las vacas afectan la eficiencia productiva del hato, al influir sobre el peso al destete de las crías $(1,2,3)$. Diferentes estudios señalan que la variación en la producción de leche de las vacas representa entre el 40 y el $65 \%$ de la variabilidad en el peso al destete de su progenie $(4,5,6)$. Conocer la cantidad de leche producida por los diferentes grupos genéticos utilizados en el sistema vaca-cría es importante para desarrollar estrategias de manejo acordes a los cambios en requerimientos de energía de las vacas durante la lactancia y a las diferencias en su potencial genético lechero ${ }^{(7)}$.

Existen estudios en ganado de carne que han estimado correlaciones importantes entre la producción de leche de las vacas y el crecimiento hasta el destete de las crías $(2,8,9)$. También hay resultados que indican que la influencia de la producción de leche sobre el crecimiento de los becerros se modifica en función del tipo racial de las vacas y de las condiciones de cada sistema de $\operatorname{producción}^{(3)}$.

Considerando la importancia que para el sistema vaca-cría tiene la producción de leche de las vacas y su relación con el peso al destete de los becerros, se planteó el presente estudio con el objetivo de evaluar características asociadas a la producción de leche de vacas Criollo, Guzerat y sus cruzas recíprocas $\mathrm{F} 1$, y para estimar las relaciones entre la producción de leche de las vacas y el peso al destete de sus crías.

El estudio se realizó en el Sitio Experimental "El Verdineño" del Instituto Nacional de Investigaciones Forestales, Agrícolas y Pecuarias (INIFAPSAGARPA), ubicado en Santiago Ixcuintla Nayarit, México, en condiciones de trópico subhúmedo $\mathrm{Aw}_{2}$, precipitación pluvial promedio de $1,200 \mathrm{~mm}$, temperatura media anual de $24^{\circ} \mathrm{C}$ y época de secas que fluctúa entre siete y ocho meses al año(10).

Las vacas de los cuatro grupos genéticos evaluados en el experimento nacieron en el Sitio Experimental "El Verdineño" a partir de un cruzamiento dialelo
Beef cattle differences in milk production of cows affect the productive efficiency of the herd through the weaning weight of calves $(1,2,3)$. Different studies point out that variation in milk production of cows reflects between 40 and $65 \%$ of the variability in the weaning weight of their offspring $(4,5,6)$. Knowing the amount of milk produced by the different genetic groups used in the cow-calf system is important for developing management strategies according to changes in energy requirements of cows during lactation, and the differences caused by their genetic potential for milk production ${ }^{(7)}$.

Research with beef cattle has been done and results have shown important correlations between milk yield of cows and preweaning growth of calves $(2,8,9)$. There are also results indicating that the influence of milk production on the growth of calves is modified depending on the breed type of cows and the conditions of each production system $(3)$.

Considering the importance to the cow-calf system of milk production of cows and its relationship to weaning weight of calves, this study was conducted with the objective of evaluating characteristics related to milk yield of Criollo, Guzerat and F1 reciprocal cross cows and to estimate the relationship between milk production of cows and weaning weight The study was carried out at El Verdineño Experimental Site of the Instituto Nacional de Investigaciones Forestales, Agrícolas y Pecuarias (INIFAP-SAGARPA) in Santiago Ixc, Nayarit, Mexico. The region has a subhumid tropical environment $\left(\mathrm{Aw}_{2}\right)$, average annual rainfall of $1,200 \mathrm{~mm}$, average annual temperature of $24{ }^{\circ} \mathrm{C}$ and a dry season of 7 to $8 \mathrm{mo}^{(10)}$.

The cows of the four genotypes used in the experiment were born at El Verdineño Experimental Site as a result of a Criollo-Guzerat diallel mating which started in 1990. Throughout the diallel mating the reproductive management of cows included two breeding seasons per year, in spring and autumn, of $60 \mathrm{~d}$ each. During this phase of the study 14 Criollo and 12 Guzerat bulls were used by natural service. The Criollo, Guzerat and reciprocal F1 
Criollo-Guzerat iniciado en 1990. Durante el cruzamiento dialelo el manejo reproductivo de las vacas incluyó dos empadres al año, en primavera y otoño, con duración de 60 días cada uno, y en los cuales se utilizaron mediante monta natural 14 toros Criollo y 12 toros Guzerat. Las hembras Criollo, Guzerat y las cruzas recíprocas F1 generadas en el dialelo se han utilizado desde entonces para estimar efectos genéticos aditivos y no aditivos para diferentes características productivas $(11,12)$. La información utilizada en el presente estudio se generó en los años 2001, 2002 y 2003 constando de 208 registros obtenidos de 134 vacas (64 Guzerat (G), 34 Criollo (C), 12 Guzerat x Criollo (GC) y 24 Criollo x Guzerat (CG)). Las variables estudiadas fueron día de máxima producción (DMP), producción máxima en lactancia (PML), producción total de leche (PTL), producción diaria de leche (PDL), persistencia de la lactancia (PER) y peso al destete ajustado a 210 días de edad (PA210) calculado como PA210 $=((($ peso al destete - peso al nacer)/edad al destete) x 210) + peso al nacer.

Durante el experimento las vacas y sus crías se mantuvieron en praderas de pasto llanero (Andropogon gayanus) con suplementación a base de melaza-urea al $2.5 \%$ (1 kg/cabeza/día) durante marzo, abril y mayo. Los animales dispusieron de una mezcla de minerales a libre acceso (sal común $40 \%$, ortofosfato de calcio $56 \%$ y minerales traza $4 \%$ ) durante todo el año. El manejo reproductivo incluyó dos empadres al año con duración de 45 días cada uno, iniciando alrededor del 15 de marzo y 15 de septiembre de cada año y en los cuales se utilizó inseminación artificial con semen de toros Angus (A). Las crías permanecieron con sus madres hasta los 7 meses de edad y se pesaron al nacer y al destete, además de los pesajes que se tomaron durante las mediciones de leche. Para medir la producción de leche se utilizó la técnica de pesaje del becerro antes y después del amamantamiento. Para asegurar que el tiempo de acumulación de leche fuera igual para todas las vacas y que los becerros tuvieran el mismo tiempo de ayuno, el día previo a la medición los becerros se separaron de females produced in the diallel mating have been used since then to estimate additive and nonadditive genetic effects for different productive traits $(11,12)$. Data for the present study (208 records from 134 cows) were collected during 2001, 2002 and 2003 from Guzerat (G), Criollo (C), Guzerat x Criollo (GC), and Criollo x Guzerat (CG) cows $(64,34$, 12 and 24 records, respectively). Traits analyzed were day of peak milk yield (DMP), maximum milk yield throughout lactation (PML), total milk yield (PTL), daily milk yield (PDL), persistency of lactation (PER), and weaning weight adjusted to $210 \mathrm{~d}$ of age (PA210) calculated as PA210 = (((weaning weight - birth weight)/age at weaning) x 210) + birth weight.

Throughout the experiment the cows and calves grazed llanero grass (Andropogon gayanus) and were supplemented with a $2.5 \%$ molasses-urea mixing $(1 \mathrm{~kg} / \mathrm{head} / \mathrm{d})$ during March, April and May. All animals had ad libitum access to minerals (40\% salt; $56 \%$ calcium orthophosphate; $4 \%$ trace minerals) all year round. Reproductive management included two breeding seasons of $45 \mathrm{~d}$ each. Breeding seasons begun on March $15^{\text {th }}$ and September $15^{\text {th }}$. Cows were bred by AI using semen of Angus bulls (A). Calves were weighed at birth and weaning and remained with their dams until weaning at 7 mo of age, on average. Milk yield was estimated using the weigh-suckle-weigh technique.

To ensure a similar milk accumulation period for all cows and to ensure that calves had the same time of fasting; cows and calves were separated at 1400 on the afternoon before sampling collection and were housed in pens in groups of 8 to 11 calves, without food or water. At 1800 of the same day calves were allowed to suckle for $20 \mathrm{~min}$ and then removed again from their dams until 0600 of the following day when milk yield was measured. For data collection the calves were weighed individually and then allowed to suckle for $20 \mathrm{~min}$. After this, the calves were weighed again and then separated of the cows until 1400 when the procedure was repeated. The consumption of milk 
las vacas a las dos de tarde y se alojaron en corraletas en grupos de ocho a once becerros, sin agua ni alimento. A las seis de la tarde del mismo día, se permitió que los becerros amamantaran durante $20 \mathrm{~min}$, y se volvieron a separar hasta las seis de la mañana del día siguiente cuando se midió la producción de leche. Para la medición los becerros se pesaron individualmente, se dejaron amamantar durante 20 min y se volvieron a pesar y a separar de las vacas hasta las dos de la tarde, cuando se repitió el mismo procedimiento. El consumo de leche se estimó como la diferencia en peso antes y después del amamantamiento. La suma de los consumos (mañana y tarde) representó la producción de leche durante $20 \mathrm{~h}$ y se multiplicó por 24/20 para estimar la producción de leche en $24 \mathrm{~h}$. Las mediciones de producción de leche se hicieron cuando las vacas tuvieron en promedio 56, 84, 112, 140, 168 y 196 días de lactancia.

Con las producciones de leche obtenidas en cada muestreo se estimó la curva de lactancia de cada vaca de acuerdo a la ecuación propuesta por Jenkins y $\operatorname{Ferrell}^{(13)}$ :

$\mathrm{Y}(\mathrm{n})=\mathrm{n} / a e^{k \mathrm{n}}$, En donde $\mathrm{Y}(\mathrm{n})=$ producción de leche en $\mathrm{kg}$ del n-ésimo día de lactancia, $\mathrm{n}=$ día de lactancia, $a$ y $k=$ parámetros que definen la curva de lactancia y $e=$ base de logaritmos naturales. Con los estimadores de los parámetros se estimaron DMP como 1/k y PML como 1/(ake); PTL se estimó como la integración matemática de la curva de lactancia a 210 días de lactación; PDL se estimó como PTL dividida entre el número de días en lactancia y PER como PTL / PML.

Para ajustar la ecuación de Jenkins y Ferrell(13) a cada una de las lactancias, se utilizó el método iterativo DUD del procedimiento para modelos no lineales del paquete estadístico SAS ${ }^{(14)}$. Los estimadores $a$ y $k$ y las variables PTL, PDL, PML, DMP y PER se analizaron por el método de cuadrados mínimos con el procedimiento de modelos mixtos para medidas repetidas (14). Los modelos para todas las variables incluyeron los efectos fijos del grupo genético de la vaca (GEN), was estimated as the difference in weight before and after nursing. The milk consumption in the morning and afternoon represented the milk production throughout $20 \mathrm{~h}$ and it was multiplied by $24 / 20$ to estimate the total milk production in $24 \mathrm{~h}$. Milk production measurements were made when the cows had on average $56,84,112,140$, 168 and $196 \mathrm{~d}$ of lactation.

Milk productions obtained in each sampling were used to estimate the lactation curve of each cow in accordance with the equation proposed by Jenkins and Ferrell(13):

$\mathrm{Y}(\mathrm{n})=\mathrm{n} / a e^{k \mathrm{n}}$, Where $\mathrm{Y}(\mathrm{n})=$ milk yield in $\mathrm{kg}$ in the n-th day of lactancy, n= day of lactancy, $a$ and $k=$ parameters defining the lactation curve and $e=$ base of natural logarithms. The estimators of the parameters were used to calculate DMP as $1 / k$ and PML as $1 /($ ake $)$; PTL was estimated as the mathematical integration of the lactation curve to $210 \mathrm{~d}$ of lactation; PDL was estimated as PTL divided by days in lactancy and PER as PTL / PML.

In order to fit the equation of Jenkins and Ferrell(13) to each of the lactations, it was used the DUD iterative method of the non linear models procedure of SAS ${ }^{(14)}$. The $a$ and $k$ estimators and the variables PTL, PDL, PML, DMP and PER were analyzed by the least squares method and the mixed models procedure for repeated measurements $(14)$. The models for all variables included the fixed effects of genetic group of the cow (GEN), number of calving (NP), year of calving (AP), season of calving (EP), sex of calf (S), birth weight as a covariate and the two factors interactions. The interactions of two factors non significant $(P>0.25)$ in preliminary analyses were not included in final models.

The general statistical model was as follows:

$\mathrm{Y}_{\mathrm{ijklmn}}=\mu+\mathrm{AP}_{\mathrm{i}}+\mathrm{EP}_{\mathrm{j}}+\mathrm{GEN}_{\mathrm{k}}+\mathrm{NP}_{1}+\mathrm{S}_{\mathrm{m}}+$ $(\mathrm{AP} * \mathrm{EP})_{\mathrm{ij}}+(\mathrm{AP} * \mathrm{GEN})_{\mathrm{ik}}+(\mathrm{AP} * \mathrm{NP})_{\mathrm{il}}+(\mathrm{AP} * \mathrm{~S})_{\mathrm{im}}$ $+(\mathrm{EP} * \mathrm{GEN})_{\mathrm{jk}}+(\mathrm{EP} * \mathrm{NP})_{\mathrm{jl}}+(\mathrm{EP} * \mathrm{~S})_{\mathrm{jm}}+$ $(\mathrm{GEN} * \mathrm{NP})_{\mathrm{kl}}+(\mathrm{GEN} * \mathrm{~S})_{\mathrm{km}}+(\mathrm{NP} * \mathrm{~S})_{\mathrm{lm}}+\mathrm{b}_{1}(\mathrm{PN}-$ $\hat{\mathrm{U}} \mathrm{PN})+\mathrm{e}_{\mathrm{ijklmn}}$ 
número de parto (NP), año de parto (AP), época de parto (EP), sexo de la cría (S), la covariable peso al nacer y las interacciones de dos factores. Las interacciones que no resultaron significativas $(P>0.25)$ en análisis preliminares, no se consideraron en los modelos finales.

El modelo estadístico general fue el siguiente:

$\mathrm{Y}_{\mathrm{ijklmn}}=\mu+\mathrm{AP}_{\mathrm{i}}+\mathrm{EP}_{\mathrm{j}}+\mathrm{GEN}_{\mathrm{k}}+\mathrm{NP}_{1}+\mathrm{S}_{\mathrm{m}}+$ $(\mathrm{AP} * \mathrm{EP})_{\mathrm{ij}}+(\mathrm{AP} * \mathrm{GEN})_{\mathrm{ik}}+(\mathrm{AP} * \mathrm{NP})_{\mathrm{il}}+(\mathrm{AP} * \mathrm{~S})_{\mathrm{im}}$ $+(\mathrm{EP} * \mathrm{GEN})_{\mathrm{jk}}+(\mathrm{EP} * \mathrm{NP})_{\mathrm{jl}}+(\mathrm{EP} * \mathrm{~S})_{\mathrm{jm}}+$ $(\mathrm{GEN} * \mathrm{NP})_{\mathrm{kl}}+(\mathrm{GEN} * \mathrm{~S})_{\mathrm{km}}+(\mathrm{NP} * \mathrm{~S})_{\mathrm{lm}}+\mathrm{b}_{1}(\mathrm{PN}-$ $\left.\hat{\mathrm{U}}_{\mathrm{PN}}\right)+\mathrm{e}_{\mathrm{ijk} \mathrm{mm}}$

Donde: $\mu=$ media general; $\mathrm{AP}_{\mathrm{i}=}$ efecto del $\mathrm{i}-$ ésimo año de parto ( $\mathrm{i}=1,2$ y 3 ); $\mathrm{EP}_{\mathrm{j}=}$ efecto de la j-ésima época de parto $(\mathrm{j}=1$ y 2$) ; \mathrm{GEN}_{\mathrm{k}=}$ efecto del k-ésimo grupo genético de la vaca $(\mathrm{k}=1,2, \ldots, 4) ; \mathrm{NP}_{1}=$ efecto del l-ésimo parto de la vaca $(l=1,2, \ldots, 5)$; $\mathrm{S}_{\mathrm{m}=}$ efecto del $\mathrm{m}$-ésimo sexo de la cría $(\mathrm{m}=1$ y 2$)$; $(\mathrm{AP} * \mathrm{EP})_{\mathrm{ij}=}=$ efecto de la interacción entre el i-ésimo año de parto y la j-ésima época de parto; $(\mathrm{AP} * \mathrm{GEN})_{\mathrm{ik}=}$ efecto de la interacción entre el i-ésimo año de parto y el k-ésimo grupo genético de la vaca; $(\mathrm{AP} * \mathrm{NP})_{\mathrm{il}}=$ efecto de la interacción entre el i-ésimo año de parto y el l-ésimo número de parto; $(\mathrm{AP} * \mathrm{~S})_{\mathrm{im}}=$ efecto de la interacción entre el i-ésimo año de parto y el m-ésimo sexo de la cría; $(\mathrm{EP} * \mathrm{GEN})_{\mathrm{jk}}=$ efecto de la interacción de la jésima época de parto y el k-ésimo grupo genético de la vaca; $(E P * N P)_{j} 1=$ efecto de la interacción de la j-ésima época de parto y el l-ésimo número de parto; $(\mathrm{EP} * \mathrm{~S})_{\mathrm{jm}=}$ efecto de la interacción de la jésima época de parto y el m-ésimo sexo de la cría; $(\mathrm{GEN} * \mathrm{NP})_{\mathrm{kl}}=$ efecto de la interacción del k-ésimo grupo genético de la vaca y del l-ésimo número de parto; $(\mathrm{GEN} * \mathrm{~S})_{\mathrm{km}=}$ efecto de la interacción del késimo grupo genético de la vaca y del m-ésimo sexo de la cría; $(\mathrm{NP} * \mathrm{~S})_{\mathrm{lm}=}$ efecto de la interacción del l-ésimo número de parto y del m-ésimo sexo de la cría; $\mathrm{PN}=$ peso al nacer como covariable; $\mathrm{b}_{1=}$ coeficiente de regresión lineal asociado con peso al nacer; $\hat{\mathrm{U}} \mathrm{PN}=$ media estimada de peso al nacer; $\mathrm{e}_{\mathrm{ijk} k \mathrm{mn}=}$ efecto residual distribuido NI $\left(0, \alpha^{2}{ }_{\mathrm{e}}\right)$.
Where: $\mu=$ overall mean; $\mathrm{AP}_{\mathrm{i}}$ the effect of the $\mathrm{i}^{\text {th }}$ year of calving ( $\mathrm{i}=1,2$ y 3$) ; \mathrm{EP}_{\mathrm{j}}=$ the effect of the $\mathrm{j}^{\text {th }}$ season of calving ( $\mathrm{j}=1$ y 2 ); $\mathrm{GEN}_{\mathrm{k}=}$ the effect of the $\mathrm{k}^{\text {th }}$ genetic group of the cow $(\mathrm{k}=1,2, \ldots, 4) ; \mathrm{NP}_{1}=$ the effect of the $1^{\text {th }}$ number of calving $(l=1,2, \ldots, 5)$; $\mathrm{S}_{\mathrm{m}=}$ the effect of the $\mathrm{m}^{\text {th }}$ sex of calf $(\mathrm{m}=1$ y 2$)$; $(\mathrm{AP} * \mathrm{EP})_{\mathrm{ij}=}$ the effect of the interaction between the $\mathrm{i}^{\text {th }}$ year of calving and the $\mathrm{j}^{\text {th }}$ season of calving; $(\mathrm{AP} * \mathrm{GEN})_{\mathrm{ik}}=$ the effect of the interaction between the $\mathrm{i}^{\text {th }}$ year of calving and the $\mathrm{k}^{\text {th }}$ genetic group of the cow; $(\mathrm{AP} * \mathrm{NP})_{\mathrm{il}}=$ the effect of the interaction between the $\mathrm{i}^{\text {th }}$ year of calving and the $\mathrm{l}^{\text {th }}$ number of calving; $(\mathrm{AP} * \mathrm{~S})_{\mathrm{im}}=$ the effect of the interaction between the $i^{\text {th }}$ year of calving and the $\mathrm{m}^{\text {th }}$ sex of calf; $(\mathrm{EP} * \mathrm{GEN})_{\mathrm{jk}=}$ the effect of the interaction between the $\mathrm{j}^{\text {th }}$ season of calving and the $\mathrm{k}^{\text {th }}$ genetic group of the cow; $(\mathrm{EP} * \mathrm{NP})_{\mathrm{jl}=}$ the effect of the interaction between the $\mathrm{j}^{\text {th }}$ season of calving and the $\mathrm{k}^{\text {th }}$ genetic group of the cow; $(E P * S)_{j m}=$ the effect of the interaction between the $j^{\text {th }}$ season of calving and the $\mathrm{m}^{\text {th }}$ sex of calf; $(\mathrm{GEN} * \mathrm{NP})_{\mathrm{kl}}=$ the effect of the interaction between the $\mathrm{k}^{\text {th }}$ genetic group of the cow and the $\mathrm{t}^{\text {th }}$ number of calving; $(\mathrm{GEN} * \mathrm{~S})_{\mathrm{km}}=$ the effect of the interaction between the $\mathrm{k}^{\text {th }}$ genetic group of the cow and the $\mathrm{m}^{\text {th }}$ sex of calf; $(\mathrm{NP} * \mathrm{~S})_{\mathrm{lm}}=$ the effect of the interaction between the $1^{\text {th }}$ number of calving and the $\mathrm{m}^{\text {th }}$ sex of calf; $\mathrm{PN}=$ birth weight as $a$ covariate; $b_{1=}$ lineal regression coefficient associated to birth weight; $\hat{\mathrm{U}} \mathrm{PN}=$ estimated average of birth weight; $\mathrm{e}_{\mathrm{ijklmn}=}$ random error NI $\left(0, \alpha^{2}{ }_{\mathrm{e}}\right)$.

Linear contrasts of least squares means were used to estimate individual heterosis $\left(\mathrm{h}^{\mathrm{i}}\right)$ and differences between direct and maternal genetic effects of $\mathrm{G}$ and $\mathrm{C}^{(15)}$. The contrast ([GC $\left.\left.+\mathrm{CG}-\mathrm{G}-\mathrm{C}\right] / 2\right)$ was used to estimate $\mathrm{h}^{\mathrm{i}}$ for DMP, PML, PTL, PDL and PER. The contrast $(\mathrm{G}+\mathrm{GC}-\mathrm{C}-\mathrm{CG})$ was used to estimate differences between direct genetic effects of $\mathrm{G}$ and $\mathrm{C}$ while differences between maternal genetic effects were estimated with the contrast (CG-GC). Covariance analyses to PA210 were conducted to estimate the effect of milk consumption on the weaning weight; this was done by including PTL as a covariate in the model. Additionally, Pearson correlation coefficients were estimated between PA210 and PTL. 
Mediante contrastes lineales de medias de cuadrados mínimos se estimó la heterosis individual $\left(h^{i}\right)$ y las diferencias entre los efectos genéticos directos y maternos de $\mathrm{G}$ y $\mathrm{C}^{(15)}$. La heterosis individual para DMP, PML, PTL, PDL y PER se estimó con el contraste ([GC $+\mathrm{CG}-\mathrm{G}-\mathrm{C}] / 2)$. Para estimar las diferencias entre los efectos genéticos directos de $\mathrm{G}$ y $\mathrm{C}$, se utilizó el contraste $(\mathrm{G}+\mathrm{GC}-\mathrm{C}-\mathrm{CG})$ mientras que con el contraste (CG-GC) se estimaron las diferencias entre los efectos genéticos maternos. Para estimar el efecto del consumo de leche sobre el peso al destete se realizaron análisis de covarianza al PA210 incluyendo en el modelo PTL como covariable. Adicionalmente se estimaron coeficientes de correlación de Pearson entre PA210 y PTL.

Efecto de grupo genético. No se detectaron diferencias significativas $(P>0.10)$ entre los grupos genéticos para el estimador $k$ (con promedios de $.0149 \pm .00052, .0148 \pm .00106, .0143 \pm .00081$ у .0157 \pm .00068 para G, GC, CG y C, respectivamente). En contraste, para el estimador $a$ el grupo genético $\mathrm{C}(5.45 \pm .33)$ fue diferente $(P<0.10)$ a los grupos genéticos GC $(4.33 \pm .51)$ y CG $(4.63 \pm .39)$ sin que se detectaran diferencias estadísticas $(P>0.10)$ con el grupo genético $\mathrm{G}$ (4.76 \pm .25). No se detectaron diferencias estadísticas $(P>0.10)$ entre las medias de cuadrados mínimos para las variables DMP o PER entre los grupos genéticos evaluados, sin embargo, para PML las vacas $\mathrm{GC}$ fueron superiores $(P<0.10)$ en 1.5 y 0.8 $\mathrm{kg}$ a las vacas $\mathrm{C}$ y $\mathrm{G}$, respectivamente (Cuadro 1). Diversos autores han evaluado PML en diferentes grupos genéticos encontrando promedios similares a los del presente estudio. Así, en un experimento en el que se compararon métodos de ordeño para vacas de siete grupos genéticos que incluyeron Hereford y Angus como razas predominantes, se determinaron promedios de PML que oscilaron entre 6 y $7 \mathrm{~kg}(16)$. Por otro lado, un promedio de $8.2 \mathrm{~kg}$ fue publicado para PML de vacas Hereford $\mathrm{x}$ Angus en su primera lactancia(17), mientras que una evaluación realizada en tres biotipos de vacas similares en talla y tasa de crecimiento corporal pero diferentes en potencial genético lechero
Effect of the genetic group of the cow. Non significant differences were detected $(P>0.10)$ among the genetic groups for the $k$ estimator (with averages of $.0149 \pm .00052, .0148 \pm .00106, .0143$ \pm .00081 and $.0157 \pm .00068$ for G, GC, CG and $\mathrm{C}$, respectively). In contrast, for the $a$ estimator the genetic group $\mathrm{C}(5.45 \pm .33)$ was different $(P<0.10)$ of the groups GC $(4.33 \pm .51)$ and CG (4.63 \pm .39), while non significant differences were detected $(P>0.10)$ with the $\mathrm{G}(4.76 \pm .25)$ group. Based on the least squares means of the variables DMP and PER non significant differences $(P>0.10)$ were detected among the genetic groups, however, the GC cows had a higher PML in 1.5 and $0.8 \mathrm{~kg}$ compared to $\mathrm{C}$ and $\mathrm{G}$ cows, respectively (Table 1). Several authors have evaluated PML in different genetic groups and have reported similar averages to those of the present study. Thus, averages of PML that ranged between 6 and $7 \mathrm{~kg}$ were established, in an experiment in which milking methods were compared for cows of seven genetic groups that included Hereford and Angus as predominant breeds $(16)$. On the other hand, an average of $8.2 \mathrm{~kg}$ was published for the PML of cows Hereford $\mathrm{x}$ Angus in its first lactancy(17), while an evaluation in three biotypes of cows of similar size and body growth but different genetic potential for milk production reported averages for PML ranging between 7.04 and $9.66 \mathrm{~kg}^{(2)}$. Another study reported averages of $5.8 \pm .5,6.8 \pm .4,7.6$ $\pm .5,8.0 \pm .5$ and $9.7 \pm .7 \mathrm{~kg}$ for the PML of Brahman and Charolais x Zebu, Hereford x Zebu, Suizo Pardo x Zebu and Angus x Zebu cows(18). In contrast, higher values for PML have been published by different authors, with averages of 10.5, 10.9 and $11.4 \mathrm{~kg}$ for Simmental cows $(9,19,20)$ and averages of 10.1, 11.1, 11.5 and $11.9 \mathrm{~kg}$ for Red Poll, Pinzgauer, Gelbvieh and Braunvieh cows $(20)$.

In Table 1 the least squares means for PTL and PDL show that GC cows were superior $(P<0.10)$ to $\mathrm{C}$ and $\mathrm{G}$ cows in 254 and $110 \mathrm{~kg}$ for PTL and in 1.1 and $0.5 \mathrm{~kg}$ for PDL, respectively. Differences were also detected between $\mathrm{G}$ and $\mathrm{C}$ cows $(P<0.10)$ favorable to $\mathrm{G}$ for PTL $(144 \mathrm{~kg})$ and PDL $(0.6 \mathrm{~kg})$. 
encontró valores para PML que oscilaron entre 7.04 y $9.66 \mathrm{~kg}^{(2)}$. En otro estudio se determinaron promedios para PML de $5.8 \pm .5,6.8 \pm .4,7.6 \pm .5$, $8.0 \pm .5$ y $9.7 \pm .7 \mathrm{~kg}$ para vacas de raza Brahman y cruzas Charolais x Cebú, Hereford x Cebú, Suizo Pardo x Cebú y Ángus x Cebú(18). En contraste, valores más altos para PML han sido publicados por diferentes autores, con promedios de 10.5, 10.9 y $11.4 \mathrm{~kg}$ para vacas $\operatorname{Simmental}(9,19,20)$ y promedios de $10.1,11.1,11.5 \mathrm{y} 11.9 \mathrm{~kg}$ para vacas Red Poll, Pinzgauer, Gelbvieh y Braunvieh(20).

En el Cuadro 1 se muestran las medias de cuadrados mínimos para PTL y PDL observándose que las vacas GC fueron superiores $(P<0.10)$ a las vacas $\mathrm{C}$ y G en 254 y $110 \mathrm{~kg}$ para PTL y en 1.1 y 0.5 kg para PDL, respectivamente. Entre vacas $\mathrm{G}$ y $\mathrm{C}$ también se detectaron diferencias $(P<0.10)$ favorables a G para PTL (144 kg) y PDL $(0.6 \mathrm{~kg})$. Coincidiendo con el presente estudio, otros autores han encontrado mayores promedios para PDL de
In agreement with the present study, other authors have found higher averages for PDL of $B$. indicus $\mathrm{x} B$. taurus cows when compared to parental breeds. Thus, experiments involving Brahman and Angus cows generated in a diallel crossing, found that Brahman x Angus and Angus x Brahman cows showed a greater PDL than Angus or Brahman cows evaluated in two ${ }^{(21)}$ or three grazing systems(3). Similarly, an evaluation involving Brahman and F1 cows reported important differences $(P<0.05)$ for the PDL of Brahman and Brown Swiss $x$ Zebu and Angus $x$ Zebu cows (4.3 $\pm 0.3,6.0 \pm 0.3$ and $6.9 \pm 0.4 \mathrm{~kg}$, respectively), without differences being detected $(P>0.05)$ between Brahman, Hereford $\mathrm{x}$ Zebu and Charolais $\mathrm{x}$ Zebu cows $(4.3 \pm 0.3,4.8 \pm 0.3$ and $4.8 \pm 0.2$ $\mathrm{kg}$, respectively) ${ }^{(18)}$. Another study carried out with cows of eight genetic groups determined a greater PDL in the $\mathrm{d} 150$ of lactation of Brahman $\mathrm{x}$ Hereford and Brahman x Angus (7.28 and 8.97 kg) cows, compared with the PDL of Hereford

Cuadro 1. Medias de cuadrados mínimos, errores estándar y heterosis individual (hi) para las características de la lactancia de vacas de cuatro grupos genéticos. Las diferencias entre los efectos genéticos directos $\left(\mathrm{g}^{\mathrm{i}}\right.$ y maternos $\left(\mathrm{g}^{\mathrm{m}}\right)$ y los coeficientes de correlación $(\boldsymbol{r})$ y regresión $(\boldsymbol{b})$ entre el peso al destete ajustado a 210 días de edad y rendimiento total de leche (PTL)

Table 1. Least squares means, standard errors and individual heterosis (hi) for characteristics of the lactancy of cows of four genetic groups. Differences between direct $\left(g^{i}\right)$ and maternal $\left(g^{m}\right)$ genetic effects and coefficients of correlation $(\boldsymbol{r})$ and regression $(\boldsymbol{b})$ between weaning weight adjusted to 210 days of age and total milk yield (PTL)

\begin{tabular}{|c|c|c|c|c|c|c|c|}
\hline GEN & PTL (kg) & PDL (kg) & $\overline{P M L ~(k g)}$ & DMP (days) & PER (days) & $\bar{r}$ & $(b)^{¥}$ \\
\hline G & $949 \pm 27 a$ & $4.5 \pm .1 \mathrm{a}$ & $6.5 \pm .1 \mathrm{a}$ & $76 \pm 2^{a}$ & $147 \pm 2^{a}$ & $0.34^{\star}$ & $0.032 \pm 0.009 *(30.9)$ \\
\hline GC & $1059 \pm 54^{b}$ & $5.0 \pm .2^{b}$ & $7.3 \pm .3^{b}$ & $74 \pm 5^{a}$ & $147 \pm 4^{a}$ & $0.49^{\star}$ & $0.037 \pm 0.014^{*}(27.3)$ \\
\hline CG & $990 \pm 42^{a b}$ & $4.7 \pm .2^{2 \mathrm{ab}}$ & $6.7 \pm .3^{a b}$ & $77 \pm 4^{a}$ & $149 \pm 3 a$ & $0.25^{\star}$ & $0.027 \pm 0.015^{\wedge}(37.3)$ \\
\hline C & $805 \pm 34 c$ & $3.9 \pm .1 \mathrm{C}$ & $5.8 \pm .2^{c}$ & $70 \pm 3^{a}$ & $143 \pm 2^{a}$ & $0.41^{*}$ & $0.044 \pm 0.014^{\star}(22.5)$ \\
\hline Global & & & & & & $0.44^{*}$ & $0.049 \pm 0.007^{*}(20.5)$ \\
\hline$h^{i}$ & $\begin{array}{l}147 \pm 44^{*} \\
(16.7 \%)\end{array}$ & $\begin{array}{c}0.6 \pm .2^{*} \\
(14.2 \%)\end{array}$ & $\begin{array}{c}0.8 \pm .3^{\star} \\
(13.0 \%)\end{array}$ & $\begin{array}{l}2.5 \pm 4^{\mathrm{ns}} \\
(3.4 \%)\end{array}$ & $\begin{array}{l}3.0 \pm 3^{n s} \\
(2.0 \%)\end{array}$ & & \\
\hline$g^{i}$ & $213 \pm 72^{*}$ & $0.9 \pm .3^{*}$ & $1.3 \pm .5^{*}$ & $3.0 \pm 7^{\text {ns }}$ & $2.0 \pm 5^{\text {ns }}$ & & \\
\hline $\mathrm{g}^{\mathrm{m}}$ & $-69 \pm 58$ ns & $-0.3 \pm .2^{n s}$ & $-0.6 \pm .4^{\mathrm{ns}}$ & $3.0 \pm 6^{\text {ns }}$ & $2.0 \pm 4^{\mathrm{ns}}$ & & \\
\hline
\end{tabular}

GEN=genetic group; $P D L=$ daily milk yield; $P M L=$ maximum milk yield; $D M P=$ day of peak milk yield; $P E R=$ persistency of lactation;

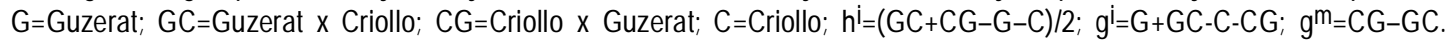

()$^{¥}$ In parentheses kilograms of milk consumed per each kilogram of body weight at weaning.

a,b,c Different letters in the same column indicate differences $(P<0.10)$ for DMP, PER, PDL, PML and PTL.

$\mathrm{ns}(P>0.05),{ }^{*}(P<0.05),{ }^{\wedge}(P<0.10)$. 
vacas $B$. indicus $x$ B. taurus cuando se comparan con las razas parentales. Así, experimentos que incluyeron vacas generadas en un cruzamiento dialelo con ganado Brahman y Angus, encontraron que vacas Brahman x Angus y Angus x Brahman mostraron una mayor PDL que las vacas Angus o Brahman cuando se evaluaron en dos(21) o tres sistemas de pastoreo $^{(3)}$. De igual manera, un trabajo en el que se evaluaron vacas F1 de cuatro grupos genéticos y vacas Brahman, se determinaron diferencias importantes $(P<0.05)$ entre la PDL de vacas Brahman y vacas Suizo Pardo x Cebú y Angus x Cebú $(4.3 \pm 0.3,6.0 \pm 0.3$ y $6.9 \pm 0.4 \mathrm{~kg}$, respectivamente), sin que las diferencias se detectaran $(P>0.05)$ entre vacas Brahman y vacas Hereford x Cebú y Charolais x Cebú $(4.3 \pm 0.3$, $4.8 \pm 0.3$ y $4.8 \pm 0.2 \mathrm{~kg}$, respectivamente)(18). Otro estudio realizado con vacas de ocho grupos genéticos determinó una mayor PDL en el día 150 de lactancia de vacas Brahman x Hereford y Brahman x Angus (7.28 y $8.97 \mathrm{~kg}$ ), comparada con la PDL de vacas Hereford $(5.81 \mathrm{~kg})$; sin embargo, la medición de PDL a los 60 días de lactancia fue mayor en las vacas Hereford (7.98 $\mathrm{kg}$ ) que en las vacas Brahman x Hereford $(7.0 \mathrm{~kg}$ ) y Brahman x Angus $(7.78 \mathrm{~kg})^{(8)}$. También se han evaluado sistemas de producción diferenciados por razas y sistemas de apareamiento encontrándose mayores promedios de PDL en sistemas de cruzamientos rotacionales que utilizaron ganado Charolais, Simmental y Main Anjou (7.36 \pm 2.75 $\mathrm{kg}$ ), y ganado Tarentaise, Pinzgauer, Gelbvieh y Angus $(6.02 \pm 2.64 \mathrm{~kg})$ comparados con la PDL estimada en ganado Hereford $(3.71 \pm 1.70 \mathrm{~kg})^{(22)}$.

En relación a PTL y coincidiendo con el presente estudio, resultados obtenidos con vacas Brahman y vacas cruzadas $B$. taurus $x$ B indicus mostraron mayores promedios de PTL $(P<0.05)$, en lactancias de 210 días, para vacas F1 Angus x Cebú $(1,454$ $\pm 92 \mathrm{~kg})$ y Suizo Pardo x Cebú $(1,256 \pm 72 \mathrm{~kg})$ comparadas con vacas Brahman (902 $\pm 72 \mathrm{~kg}$ ), en contraste, el mismo estudio no detectó diferencias $(P>0.05)$ entre la PTL de vacas Brahman y vacas Hereford x Cebú $(1,008 \pm 70 \mathrm{~kg})$ y Charolais $\mathrm{x}$ Cebú $(1,012 \pm 62 \mathrm{~kg})^{(18)}$. Asimismo, otro estudio
$(5.81 \mathrm{~kg})$ cows, however, measurements of PDL at $60 \mathrm{~d}$ of lactation were greater in Hereford (7.98 $\mathrm{kg}$ ) than in Brahman $\mathrm{x}$ Hereford $(7.0 \mathrm{~kg})$ and Brahman x Angus cows $(7.78 \mathrm{~kg})^{(8)}$. Production systems differentiated by breeds and mating systems have also been evaluated and results have shown higher PDL averages for rotational crossbreeding systems with Charolais, Simmental and Main Anjou cattle $(7.36 \pm 2.75 \mathrm{~kg})$, and Tarentaise, Pinzgauer, Gelbvieh and Angus cattle $(6.02 \pm 2.64 \mathrm{~kg})$ compared to the PDL of Hereford cattle (3.71 \pm $1.70 \mathrm{~kg})^{(22)}$.

In relation to PTL and coinciding with the present study, results obtained with Brahman and crossbred $B$. taurus $\mathrm{x} B$. indicus cows, showed higher averages for PTL $(P<0.05)$ at $210 \mathrm{~d}$ of lactancy, of $\mathrm{F} 1$ Angus x Zebu $(1,454 \pm 92 \mathrm{~kg})$ and Brown Swiss x Zebu $(1,256 \pm 72 \mathrm{~kg})$ cows compared to Brahman $(902 \pm 72 \mathrm{~kg})$ cows; in contrast, the same study did not detect differences $(P>0.05)$ between the PTL of Brahman cows and Hereford $x$ Zebu $(1008 \pm 70 \mathrm{~kg})$ and Charolais x Zebu (1,012 \pm 62 $\mathrm{kg})$ cows $(18)$. Similarly, another study found a greater PTL of Angus x Brahman cows compared with Angus or Brahman cows (23). In the same way, a diallel crossing including Brahman, Angus and Hereford breeds detected higher values of PTL for lactations at $175 \mathrm{~d}$ of $\mathrm{F} 1$ Angus $\mathrm{x}$ Brahman (812 \pm $115 \mathrm{~kg}$ ) cows compared to the PTL of Brahman $(737 \pm 187 \mathrm{~kg})$ cows, however, F1 Hereford $\mathrm{x}$ Brahman cows had less PTL $(646 \pm 124 \mathrm{~kg})$ than Brahman(24). Previous results show increases in the PTL of Angus x Brahman compared to Hereford $\mathrm{x}$ Brahman and Brahman, a higher PTL of Angus $(1,423 \pm 56 \mathrm{~kg})$ cows has also been established compared to Hereford $(1,191 \pm 57 \mathrm{~kg})$ cows considering lactations of $210 \mathrm{~d}^{(20)}$. Similarly the PTL of Angus, Hereford and Simmental cows has been evaluated with results showing, at $205 \mathrm{~d}$ of lactancy, superiority of Simmental cows over Hereford cows $(1,434 \text { vs } 1,084 \mathrm{~kg})^{(19)}$ and over Angus cows $(1,724 \pm 47 \text { vs } 1,454 \pm 37 \mathrm{~kg})^{(9)}$. In general, results of this study and information published by several authors agree in pointing to the genetic group as an important factor that 
determinó una mayor PTL de las vacas Angus x Brahman comparadas con vacas Angus o Brahman(23). De igual manera, un cruzamiento dialelo en el que se incluyeron las razas Brahman, Angus y Hereford detectó mayores PTL para lactancias a 175 días de vacas F1 Angus x Brahman $(812 \pm 115 \mathrm{~kg})$ comparada con la PTL de vacas Brahman $(737 \pm 187 \mathrm{~kg})$, sin embargo, vacas F1 Hereford x Brahman tuvieron menor PTL (646 \pm $124 \mathrm{~kg}$ ) que las vacas Brahman(24). Los resultados previos muestran incrementos en la PTL de vacas Angus x Brahman comparadas con vacas Hereford x Brahman y Brahman, también se ha determinado una mayor PTL de vacas Angus $(1,423 \pm 56 \mathrm{~kg})$ comparadas con vacas Hereford $(1,191 \pm 57 \mathrm{~kg})$ evaluadas en lactancias de 210 días(20). De igual manera se ha evaluado la PTL de vacas Angus, Hereford y Simmental encontrándose, a 205 días de lactancia, superioridad de las vacas Simmental sobre vacas Hereford $(1,434 \text { vs } 1,084 \mathrm{~kg})^{(19)}$ y sobre vacas Angus (1,724 \pm 47 vs 1,454 \pm 37 $\mathrm{kg})^{(9)}$. En general, los resultados del presente estudio y la información publicada por diversos autores coinciden en señalar al grupo genético como un factor importante que determina la producción de leche de vacas que producen becerros para la engorda. Además de grupo genético, otros estudios han planteado que factores ambientales como la época de nacimiento de las becerras o su edad al destete influyen sobre la producción de leche de estas hembras al modificar su tasa de crecimiento

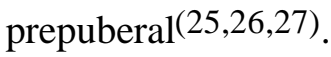

\section{Heterosis individual}

En el Cuadro 1 se muestran los estimadores de $\mathrm{h}^{\mathrm{i}}$ para las variables DMP, PML, PTL, PDL y PER. Los efectos de $h^{\mathrm{i}}$ no influyeron significativamente $(P>0.05)$ sobre DMP y PER, en contraste, $\mathrm{h}^{\mathrm{i}}$ si influyó $(P<0.05)$ sobre las variables PML, PTL y PDL. La importancia de la heterosis para influir favorablemente las características de la lactancia ha sido establecida por diferentes experimentos. Así, resultados publicados para PDL de vacas F1 $B$. taurus $x B$. indicus señalan valores de heterosis que van desde $1.55 \pm 0.34$ hasta $2.36 \pm 0.33 \mathrm{~kg}$ y determines milk production of cows producing feedlot calves.

In addition to genetic group, other studies have stated that environmental factors as season of birth of the heifers or their age at weaning has an influence on the milk production of these heifers through the modification of its prepubertal growth rate $(25,26,27)$.

\section{Individual heterosis}

Estimators for $\mathrm{h}^{\mathrm{i}}$ and the variables DMP, PML, PTL, PDL and PER are shown in Table 1. The $\mathrm{h}^{\mathrm{i}}$ effects did not have a significant influence $(P>0.05)$ on DMP and PER, in contrast, $\mathrm{h}^{\mathrm{i}}$ influenced $(P<0.05)$ the variables PML, PTL and PDL. Different experiments have established the importance of the heterosis to influence in a favorable way the characteristics of the lactancy. Thus, results published for PDL of F1 B. taurus $\mathrm{x}$ $B$. indicus cows indicate values of heterosis ranging from $1.55 \pm 0.34 \mathrm{~kg}$ and $36.9 \%$ until $2.36 \pm 0.33 \mathrm{~kg}$ and $43.8 \%(21)$ and from $2.0 \pm 0.6 \mathrm{~kg}$ and $23.7 \%$ until $2.7 \pm 0.6 \mathrm{~kg}$ and $52.8 \%(28)$ for cows Brahman $x$ Angus managed in two or three grazing systems. In coincidence with the foregoing, the present study established a heterosis value of $0.6 \pm 0.2 \mathrm{~kg}(14.2 \%)$ for the PDL of GC cows (Table 1). It is necessary to point out that lower values of heterosis have been estimated for PDL when $B$. taurus $x B$. taurus crosses have been evaluated, with averages of 8 and $15 \%(0.22$ and $0.4 \mathrm{~kg})$ for Hereford $\mathrm{x}$ Ángus cows $(29,30), 11 \%(0.93 \mathrm{~kg})$ for Hereford $\mathrm{x}$ Red Poll cows $(8)$ and $12.1 \%(1.05 \mathrm{~kg})$ for Hereford $\mathrm{x}$ Tarentaise cows $(31)$. Previous results show that higher levels of heterosis are possible when crosses are conducted between $B$. taurus and B. indicus breeds which is explained by the great genetic divergence between the aforementioned breeds.

\section{Direct and maternal genetic effects}

Favorable differences were detected for Guzerat compared to Criollo $(P<0.05)$ between the direct genetic effects for PML, PTL and PDL (Table 1). In coincidence with this result, other studies have also detected favorable direct genetic effects for 
36.9 hasta $43.8 \%(21)$ y desde $2.0 \pm 0.6$ hasta 2.7 $\pm 0.6 \mathrm{~kg}$ y 23.7 hasta $52.8 \%(28)$ para vacas Brahman x Angus manejadas en dos y tres sistemas de pastoreo. En coincidencia con lo anterior, en el presente estudio se estableció un valor de heterosis de $0.6 \pm 0.2 \mathrm{~kg}(14.2 \%)$ para la PDL de vacas GC (Cuadro 1). Cabe señalar que valores menores de heterosis para PDL han sido estimados cuando se evalúan cruzamientos $B$. taurus $\times$ B . taurus, con promedios de 8 y $15 \%(0.22$ y $0.4 \mathrm{~kg})$ para vacas Hereford x Angus (29,30), $11 \%$ (0.93 kg) para vacas Hereford x Red Poll( $\left.{ }^{8}\right)$ y $12.1 \%(1.05 \mathrm{~kg}$ ) para vacas Hereford $\mathrm{x}$ Tarentaise ${ }^{(31)}$. Los resultados previos muestran que son posibles mayores niveles de heterosis cuando se realizan cruzamientos entre razas $B$. taurus y razas $B$. indicus lo cual se explica por la gran divergencia genética entre las razas mencionadas.

\section{Efectos genéticos directos y maternos}

Se detectaron diferencias favorables a Guzerat sobre Criollo $(P<0.05)$ entre los efectos genéticos directos de PML, PTL y PDL (Cuadro 1). Coincidiendo con este resultado, otros estudios también han detectado efectos genéticos directos favorables para PDL de vacas de razas $B$. indicus comparadas con vacas de razas $B$. taurus. Así, un análisis en el que se estimaron diferencias entre los efectos genéticos directos de Brahman y Angus para PDL, determinó una diferencia promedio de $2.2 \pm 1.3 \mathrm{~kg}$ favorable $(P<0.11)$ a Brahman(28). De igual manera, datos obtenidos en un estudio con ganado Brahman y Angus estableció la importancia relativa de los efectos genéticos directos para PDL favorables $(P<0.05)$ a la raza Brahman ${ }^{(21)}$. En contraste con los resultados previos, un experimento en el que se comparó la PDL de razas $B$. taurus estimó diferencias insignificantes $(P>0.05)$ para la producción de leche de vacas Tarentaise y Hereford evaluadas al inicio $(-0.22 \mathrm{~kg})$ y al final de la lactancia $(-0.51 \mathrm{~kg})^{(31)}$. Por otro lado, un estudio realizado con ganado Hereford y Angus estableció diferencias de $0.8 \mathrm{~kg}$ entre los efectos genéticos directos para la PDL de las razas mencionadas $(30)$. No se detectaron diferencias $(P>0.05)$ entre los the PDL of cows of $B$. indicus breeds compared to cows of $B$. taurus breeds. Thus, an analysis in which differences were estimated between the direct genetic effects for the PDL of Brahman and Angus cows, an average difference of $2.2 \pm 1.3 \mathrm{~kg}$ favorable $(P<0.11)$ to Brahman was determined $(28)$. Similarly, the importance of the direct genetic effects favorable $(P<0.05)$ to Brahman was established from data obtained in a study with Brahman and Angus cattle(21). In contrast with previous results, an experiment comparing the PDL of $B$. taurus breeds estimated insignificant differences $(P>0.05)$ for milk production of Tarentaise and Hereford cows evaluated at the beginning $(-0.22 \mathrm{~kg})$ and at the end of the lactancy $(-0.51 \mathrm{~kg})^{(31)}$. On the other hand, a study conducted with Hereford and Angus cattle established differences of $0.8 \mathrm{~kg}$ between the direct genetic effects for the PDL of the mentioned breeds $(30)$. Differences were not detected $(P>0.05)$ between the maternal genetic effects for none of the analyzed variables, nevertheless, the estimated averages for PTL, PDL and PML show a favorable tendency to Criollo (Table 1). In contrast, a study detected favorable $(P<0.01)$ maternal genetic effects for PDL in B. taurus (Angus) populations compared to $B$. indicus populations (Brahman) when compared at 145 and $177 \mathrm{~d}$ of lactancy of cows in Bermuda prairies, however, the same experiment did not detect differences between maternal genetic effects of cows in Festuca prairies(21). Differences between maternal genetic effects for PDL were also found between Hereford and Angus cows (721 \pm $227 \mathrm{~g})$ at $6 \mathrm{wk}$ of lactancy $(P<0.01)$, between Hereford and Shorthorn cows $(708 \pm 299 \mathrm{~g})$ at 4 mo of lactancy $(P<0.05)^{(29)}$ and between Tarentaise and Hereford $(P<0.05)$ at the beginning $(2.16 \mathrm{~kg})$ and at the end of lactancy $(3.77 \mathrm{~kg})^{(31)}$. In coincidence with the present study, other authors have established irrelevant differences between the maternal genetic effects of Red Poll and Hereford cows $(8)$ and Angus and Brahman cows $(28)$.

Relationships between milk yield of cows and weaning weight of calves

The estimated correlations between PTL and PA210 were significant $(P<0.05)$ for all the genetic groups 
efectos genéticos maternos para ninguna de las variables analizadas; sin embargo, los promedios estimados para PTL, PDL y PML coinciden en mostrar una tendencia favorable a Criollo (Cuadro 1). En contraste, un estudio detectó efectos genéticos maternos favorables $(P<0.01)$ para PDL en poblaciones $B$. taurus (Angus) comparadas con poblaciones B. indicus (Brahman) a los 145 y 177 días de lactancia de vacas en pastoreo de Bermuda, sin embargo, el mismo experimento no detectó diferencias entre efectos genéticos maternos de vacas en pastoreo de Festuca(21). Diferencias entre efectos genéticos maternos para PDL también fueron encontradas entre vacas Hereford y Angus $(721 \pm 227 \mathrm{~g})$ a las 6 semanas de lactancia $(P<0.01)$, entre vacas Hereford y Shorthorn $(708 \pm$ $299 \mathrm{~g})$ a los cuatro meses de lactancia $(P<0.05)^{(29)}$ y entre vacas Tarentaise y Hereford $(P<0.05)$ al inicio $(2.16 \mathrm{~kg})$ y al final de la lactancia $(3.77$ $\mathrm{kg})^{(31)}$. En coincidencia con el presente estudio, otros autores han establecido diferencias irrelevantes entre los efectos genéticos maternos de vacas Red Poll y Hereford ${ }^{(8)}$ y de vacas Angus y Brahman(28).

Relaciones entre producción de leche de las vacas y peso al destete de las crías

Las correlaciones estimadas entre PTL y PA210 fueron significativas $(P<0.05)$ en todos los grupos genéticos evaluados (Cuadro 1). La diferencia entre las correlaciones estimadas para las cruzas recíprocas indica una mayor asociación entre la producción de leche de las vacas GC y el peso al destete de sus crías $(r=0.49)$ comparada con la asociación entre vacas CG y sus crías $(r=0.25)$. Esto sugiere que la recomendación de utilizar vacas GC o CG para la producción de becerros al destete debe incluir la utilización de estrategias diferentes para el manejo alimenticio durante la lactancia de cada uno de estos genotipos. Por otro lado, la correlación conjunta entre PTL y PA210 de los cuatro grupos genéticos en el presente estudio fue de $0.44(P<0.05)$ (Cuadro 1), similar a las correlaciones estimadas en poblaciones $B$. taurus y $B$. taurus $x$ B. taurus $(r=0.50)^{(1)}$, en poblaciones $B$. taurus y $B$. indicus $x$ B. taurus $(r=0.40)^{(32)}$, en
(Table 1). The difference between the estimated correlations for the reciprocal crosses indicate a stronger association between the milk yield of GC cows and the weaning weight of their calves ( $r=$ 0.49) compared to the association between CG cows and their calves $(r=0.25)$. This suggests that the recommendation to use cows GC or GC for the production of calves at weaning should include the use of different strategies for the feeding management during lactation of each of these genotypes. On the other hand, $0.44(P<0.05)$ was the joint correlation between PTL and PA210 of the four genetic groups in the present study (Table 1 ), similar to the estimated correlations in B. taurus and B. taurus $\times$ B. taurus populations $(r=0.50)^{(1)}$, in $B$. taurus and B. indicus $x B$. taurus populations $(r=0.40)^{(32)}$, in Angus $(r=0.30)$ and Simmental populations $(r=0.47)^{(9)}$ and in $B$. indicus and $B$. indicus $x$ B. taurus populations $(r=0.45)^{(18)}$. In contrast, correlation coefficients of 0.60 and 0.88 between milk yield and weaning weight have been published for several authors $(2,4,6,16)$. It should be noted that, in general, it has been established that the correlation between milk yield and preweaning growth decreases as lactancy is progressing, which may be explained to a large extent by a gradual increase in the forage consumption by calves during the birth - weaning period $(2,5,8,33)$.

Table 1 shows the estimated regression coefficients $(P<0.05)$ for the four evaluated genetic groups. The highest regression coefficients of PA210 on PTL corresponded to the genetic groups $\mathrm{C}$ and $\mathrm{GC}$ which suggests that progeny from Criollo dams or granddams had a lesser nutritional dependence from milk and depended to a larger extent on alternative feeding sources which had a lower nutritional value. The foregoing according to the proposal by Clutter and Nielsen ${ }^{2}$ ) who assessed the effect of milk yield on growth, before and after weaning, of progeny from cows with different genetic potential for milk production, finding that the highest regression coefficient was estimated for the group of cows with the lower genetic potential. In a similar way, several studies have detected a stronger relationship between milk yield and preweaning growth in 
poblaciones Angus $(r=0.30)$ y Simmental $(r=$ $0.47)^{(9)}$ y en poblaciones $B$. indicus y $B$. indicus $x$ B. taurus $(r=0.45)^{(18)}$. En contraste, coeficientes de correlación entre 0.60 y 0.88 para producción de leche y peso al destete han sido publicados por diferentes autores $(2,4,6,16)$. Cabe señalar que, en general, se ha establecido que la correlación entre producción de leche y ganancia diaria predestete disminuye conforme avanza la lactancia, lo que se explica en gran medida, por un incremento gradual en el consumo de forraje por parte de las crías durante el período nacimiento - destete $(2,5,8,33)$.

En el Cuadro 1 se muestran los coeficientes de regresión estimados $(P<0.05)$ para los cuatro grupos genéticos evaluados. Los mayores coeficientes de regresión de PA210 sobre PTL correspondieron a los grupos genéticos $\mathrm{C}$ y GC, lo que sugiere que crías de madres o abuelas Criollo tuvieron una menor dependencia nutricional de la leche materna y dependieron en gran medida de fuentes alimenticias alternas de menor valor nutricional. Lo anterior de acuerdo a lo propuesto por Clutter y Nielsen(2) quienes evaluaron el efecto de la producción de leche sobre el crecimiento antes y después del destete de crías de vacas con diferente potencial genético lechero, encontrando que el coeficiente de regresión más alto correspondió al grupo de vacas con potencial lechero más bajo. De manera similar, diferentes estudios han estimado una relación más fuerte entre producción de leche $\mathrm{y}$ crecimiento predestete en poblaciones con bajo potencial lechero $(3,19,34)$. En contraste con lo anterior, un estudio realizado con ganado Simmental y Angus encontró que la mayor relación entre crecimiento predestete y producción de leche ocurrió en la población Simmental, que produjo la mayor cantidad de leche(9); por otro lado, coeficientes de regresión similares se estimaron en poblaciones manejadas en tres sistemas de producción diferenciados por su producción de leche(22).

En relación a los kilogramos de leche por lactancia requeridos por cada grupo genético para producir $1 \mathrm{~kg}$ de peso al destete, los resultados del presente populations with lower genetic potential for milk production $(3,19,34)$. In contrast to the above, a study conducted with Simmental and Angus cattle found that the strongest relationship between milk yield and preweaning growth occurred in the Simmental population which had the highest milk yield(9), on the other hand, similar regression coefficients were estimated for populations managed in three production systems which differed by their milk $\operatorname{production}^{(22)}$.

About the kilograms of milk per lactation required by each genetic group to produce $1 \mathrm{~kg}$ of weight at weaning, results of this study show a more efficient use of the available milk by the progeny of $\mathrm{C}$ and GC cows with an intake of 22.5 and $27.3 \mathrm{~kg}$ of milk per each kilogram of weight at weaning, on average, while the milk intake was of 30.9 and $37.3 \mathrm{~kg}$ by the progeny of $\mathrm{G}$ and $\mathrm{CG}$ cows, respectively (Table 1). It is important to highlight the $10 \mathrm{~kg}$ of difference on the milk intake between progeny of $\mathrm{CG}$ and $\mathrm{GC}$ cows to produce $1 \mathrm{~kg}$ of weight at weaning. The above-mentioned difference must be taken into account in making recommendations on the use of these genetic groups for the production of calves in the cow-calf system. Similar averages to those in the present study have been estimated for milk intake of calves from Angus, Brahman, Angus x Brahman and Brahman x Angus cows (with 19.34, 22.52, 33.44 and $43.85 \mathrm{~kg}$ of milk intake per $\mathrm{kg}$ of weight at weaning) ${ }^{(3)}$. Also, in another experiment to analyze the preweaning growth of calves from cows of three genetic groups differing in genetic potential for milk production, requirements of $18.87,31.25$ and $31.25 \mathrm{~kg}$ of milk intake per $\mathrm{kg}$ of weight at weaning were estimated for progeny of cows with high, medium and low genetic potential, respectively(2).

It was concluded that the genetic group was identified as an important factor to determine milk yield. The individual heterosis had a positive influence on several characteristics of the lactancy. Differences in direct genetic effects were favorable to Guzerat for milk yield. The estimated correlations indicate significant associations between PTL and 
estudio (Cuadro 1) sugieren un uso más eficiente de la leche disponible por parte de las crías de vacas $\mathrm{C}$ y $\mathrm{GC}$ que consumieron, en promedio, 22.5 y $27.3 \mathrm{~kg}$ de leche por cada kilogramo de peso al destete, mientras que el consumo de las crías de vacas $G$ y $C G$ fue de 30.9 y $37.3 \mathrm{~kg}$, respectivamente. Es importante resaltar la diferencia de $10 \mathrm{~kg}$ de leche consumida, entre crías de vacas CG y GC, para producir $1 \mathrm{~kg}$ de peso al destete. La diferencia mencionada debe tomarse en cuenta al hacer recomendaciones sobre el uso de estos grupos genéticos para la producción de becerros al destete. Promedios similares a los del presente estudio han sido estimados para consumo de leche de crías de vacas Angus, Brahman, Angus x Brahman y Brahman x Angus (con 19.34, 22.52, 33.44 y $43.85 \mathrm{~kg}$ de leche consumida por $\mathrm{kg}$ de peso al destete) $)^{(3)}$. Asimismo, en otro experimento en el que se analizó el crecimiento predestete de crías de vacas de tres grupos genéticos con diferente potencial genético lechero se estimaron requerimientos de $18.87,31.25$ y $31.25 \mathrm{~kg}$ de leche por kilogramo de peso al destete para crías de vacas de bajo, mediano y alto potencial lechero, respectivamente ${ }^{(2)}$.

\section{CONCLUSIONES E IMPLICACIONES}

Se identificó al grupo genético como factor importante para determinar la producción de leche. La heterosis individual influyó positivamente varias características de la lactancia. Para producción de leche se detectaron diferencias favorables a Guzerat en efectos genéticos directos. Las correlaciones obtenidas indican asociaciones importantes entre PTL y PA210 en los cuatro grupos genéticos evaluados. Los coeficientes de regresión sugieren un uso más eficiente de la leche consumida por las crías de vacas Criollo y Guzerat x Criollo. Entre las cruzas recíprocas se estimó una diferencia importante en la leche requerida para producir 1 $\mathrm{kg}$ de peso al destete, lo que refleja diferencias en la eficiencia de utilización de la leche consumida por las crías de vacas Guzerat x Criollo en relación a las crías de vacas Criollo x Guzerat. En general, las diferencias estimadas en la eficiencia de
PA210 for the four evaluated genetic groups. The regression coefficients suggest a more efficient use of the milk consumed by calves from Criollo and Guzerat x Criollo cows. An important difference in the milk required to produce $1 \mathrm{~kg}$ of weight at weaning, was estimated between the reciprocal crosses, which reflects differences in the efficiency of use of milk consumed by the progeny of Guzerat $\mathrm{x}$ Criollo cows in relation to the progeny of Criollo $x$ Guzerat cows. In general, the estimated differences for the efficiency of usage of milk consumed by the offspring suggest that production of feedlot calves with Guzerat, Guzerat x Criollo, Criollo x Guzerat and Criollo cows must consider different strategies of feeding throughout the lactancy period of each genetic group.

\section{End of english version}

utilización de la leche consumida por las crías sugieren que la producción de becerros con vacas Guzerat, Guzerat x Criollo, Criollo x Guzerat y Criollo debe considerar estrategias diferentes de alimentación durante la lactancia para cada grupo genético.

\section{LITERATURA CITADA}

1. Jeffery HB, Berg RT. Evaluation of milk variables as measures of milk effect on preweaning performance of beef cattle. Can J Anim Sci 1971;(51):21-30.

2. Clutter AC, Nielsen MK. Effect of level of beef cow milk production on pre- and postweaning calf growth. J Anim Sci 1987;(64):1313-1322.

3. Brown MA, Brown Jr AH. Relationship of milk yield and quality to preweaning gain of calves from Angus, Brahman and reciprocal-cross cows on different forage system. J Anim Sci 2002;(80):2522-2527.

4. Neville JR WE. Influence of dam's milk production and other factors on 120- and 240-day weight of Hereford calves. J Anim Sci 1962;(21):315-320.

5. Rutledge JJ, Robinson OW, Ahlschwede WT, Legates JE. Milk Yield and its Influence on 205-Day Weight of Beef Calves. J Anim Sci 1971;(33):563-567.

6. Robison OW, Yusuff MKM, Dillard EU. Milk production in Hereford cows I. Means and correlations. J Anim Sci 1978;(47):131-136 
7. Montaño BM, Nielsen MK, Deutscher GH. Energy requirements for maintenance of crossbred beef cattle with different genetic potential for milk. J Anim Sci 1990;(68):22792288 .

8. Daley DR, McCuskey A, Bailey CM. Composition and yield of milk from Beef-type Bos Taurus and Bos Indicus x Bos Taurus dams. J Anim Sci 1987;(64):373-784.

9. Marston TT, Simms DD, Schalles RR, Zoellner KO, Martin LC, Fink GM. Relationship of milk production, milk expected progeny difference, and calf weaning weight in Angus and Simmental cow-calf pairs. J Anim Sci 1992;(70):3304-3310.

10. Sistema Estatal de Monitoreo Agroclimático Nayarit. Estación Meteorologica: El Verdineño-INIFAP; 2007.

11. Martínez VG, Montaño BM, Palacios FJA. Efectos genéticos directos, maternos y heterosis individual para tasas de estro, gestación, parición y destete de vacas Criollo, Guzerat y sus cruzas F1. Téc Pecu Méx 2006;44(2):143-154.

12. Martínez VG, Palacios FJA, Bustamante GJJ, Rios UA, Vega MVE, Montaño BM. Composición de leche de vacas Criollo, Guzerat y sus cruzas F1 y su relación con el peso al destete de las crías. Rev Mex Cienc Pecu 2010;1(4):311-324

13. Jenkins TG, Ferrell CL. A note on lactation curves of crossbred cows. Anim Prod 1984;(39):479-485.

14. SAS. SAS User's Guide: Statistics (version 7 ed.). Cary NC, USA: SAS Inst. Inc. 1998.

15. Dickerson GE. Experimental approaches in utilizing breed resources. Anim Breed Abstr 1969;(37):191-202.

16. Totusek R, Arnett DW, Holland GL, Whiteman JV. Relation of estimation method, sampling interval and milk composition to milk yield of beef cows and calf gain. J Anim Sci 1973;(37):153158.

17. Reynolds CK, Tyrrel HF. Energy metabolism in lactating beef heifers. J Anim Sci 2000;(78):2696-2705.

18. Quiroz VJ. Producción y componentes de leche en vacas Bos indicus y Bos taurus x Bos indicus [tesis maestría]. México DF: Universidad Nacional Autónoma de México; 1994.

19. Mallinckrodt CH, Bourdon RM, Golden BL, Schalles RR, Odde KG. Relationship of maternal milk expected progeny differences to actual milk yield and calf weaning weight. J Anim Sci 1993;(71):355-362.

20. Jenkins TG, Ferrell CL. Lactation characteristics of nine breeds of cattle fed various quantities of dietary energy. J Anim Sci 1992;(70):1652-1659.

21. Brown MA, Brown Jr AH, Jackson WG, Miesner JR. Milk production in Angus, Brahman, and reciprocal-cross cows grazing common bermuda grass or endophyte-infected tall fescue. J Anim Sci 1996;(74):2058-2066.
22. Miller SP, Wilton JW, Pfeiffer WC. Effects of milk yield on biological efficiency and profit of beef production from birth to slaughter. J Anim Sci 1999;(77):344-352.

23. Reynolds WL, DeRouen TM, Meyerhoeffer DC. Milk production of Angus, Brahman and Zebu-cross cows [abstract]. J Anim Sci 1967;(26):206.

24. Sacco RE, Baker JF, Cartwrigth TC. Production characters primiparous females of a five-breed diallel. J Anim Sci 1987;(64):1612-1618.

25. Buskirk DD, Faulkner DB, Hurley WL, Kesler DJ, Ireland FA, Nash TG, Castree JC, Vicini JL. Growth, reproductive performance, mammary development, and milk production of beef heifers as influenced by prepubertal dietary energy and administration of bovine somatotropin. J Anim Sci 1996;(74):2649-2662.

26. Sejrsen K, Purup S, Vestergaard M, Foldager J. High body weight gain and reduced bovine mammary growth: Physiological basis and implications for milk yield potential. Domest Anim Endocrinol 2000;(19):93-104.

27. Grings EE, Roberts AJ, Geary TW, MacNeil MD. Milk yield of primiparous beef cows from three calving systems and varied weaning ages. J Anim Sci 2008;(86):768-779.

28. Brown MA, Brown Jr AH, Jackson WG, Miesner JR. Genotype $\mathrm{x}$ environment interactions in milk yield and quality in Angus, Brahman, and reciprocal-cross cows on different forage systems. J Anim Sci 2001;(79):1643-1649.

29. Cundiff LV, Gregory KE, Schwulst J, Koch RM. Effects of Heterosis on Maternal Performance and Milk Production in Hereford, Angus and Shorthorn Cattle. J Anim Sci 1974;(38):728-745.

30. Notter DR, Cundiff LV, Smith GM, Laster DB, Gregory KE. Characterization of biological types of cattle. VII. Milk production in young cows and transmitted and maternal effects on preweaning growth of progeny. J Anim Sci 1978;(46):908921.

31. Kress DD, Doornbos DE, Anderson DC, Davis KC. Genetic Components for Milk Production of Tarentaise, Hereford, and Tarentaise x Hereford cows. J Anim Sci 1996;(74):2344-2348.

32. McCarter MN, Buchanan DS, Frahm RR. Comparison of crossbred cows containing various proportions of Brahman in spring or fall calving systems: Milk production. J Anim Sci 1991;(69):77-84

33. Gleddie VM, Berg RT. Milk production in range beef cows and its relationship to calf gains. J Anim Sci 1968;(48):323333.

34. Fiss CF, Wilton JW. Contribution of breed cow weight, and milk yield to the preweaning feedlot, and carcass traits of calves in three beef breeding systems. J Anim Sci 1993;(71):2874-2884. 